\title{
Water theft in rural contexts
}

Rob White

Distinguished Professor of Criminology

School of Social Sciences

University of Tasmania

AUSTRALIA

Contact author-Rob White: r.d.white@utas.edu.au; +61 362262877

\begin{abstract}
Water theft is a phenomenon that is set to grow in the light of climate change, chronic drought, freshwater scarcity, and conflicts over natural resources. Drawing upon recent developments pertaining to poor regulation and the stealing of water from the MurrayDarling river system in Australia, this paper explores the cultural and political economic dimensions of water theft in the context of rurality and criminality. Framed within the overarching perspective of green criminology, the article examines water theft through the lens of rural folk crime as well as failures of regulation and environmental law enforcement. It raises issues relating to the social construction of victims of water theft, human (such as Indigenous people) and non-human (such as ecosystems). This article argues that the geographical location of water theft is integral to the dynamics of the harms committed, and the response of both governments and residents to the crime.
\end{abstract}

Key words: water theft; green criminology; rural folk crime; Murray-Darling river; environmental regulation 


\section{Water theft in rural contexts - White}

\section{Introduction}

In July 2017, an Australian Broadcasting Corporation Four Corners investigation revealed a series of improper conducts pertaining to the Murray-Darling Basin, the largest fresh-water system in Australia (ABC, 2017). Four Corners is a long-running investigative current affairs television program produced by the national public broadcaster (the ABC). Specifically, it was alleged that in New South Wales:

- huge amounts of water were being diverted (stolen) for use by large agriculture companies upstream - more than they were entitled to ( 1.1 billion gigalitres for one property alone);

- there was pump tampering and failure to keep diaries and logs;

- the top regulator in New South Wales, Gavin Hanlon, had offered to help lobbyists campaign against the Murray-Darling Basin plan (by sending deidentified government documents to industry people); and

- the Strategic Investigations Unit in New South Wales was disbanded at precisely the time when it was asking for more resources to address significant problems (compliance was moved out of the relevant government department).

The broadcast led to no less than eight official inquiries into these issues (MurrayDarling Basin Authority, 2017; Craik, 2018), involving federal and state agencies, anticorruption and water management groups, the New South Wales Ombudsman, and a South Australian Murray-Darling Basin Royal Commission.

The Murray-Darling Basin Plan (MDBP) refers to an inter-governmental attempt to manage water resources in south-east Australia. The Murray-Darling is the largest and most complex river system in Australia, coving one million square kilometres traversing the States of New South Wales, Queensland, South Australia and Victoria, and the Australian Capital Territory (which is geographically located within New South Wales) (refer to Figure 1).

The Australian Government works in partnership with these governments with the aim to bring the Basin back to a healthier and sustainable level, while continuing to support farming and other industries for the benefit of the Australian community (Murray-Darling Basin Authority, 2019). Basin state and territory governments manage the water in their own areas, in line with nationally agreed principles and plans. The Australian Government minister responsible for water accredits the states' water resource plans, which set the local rules for water use. At least initially, most of the public attention regarding 'stolen' water focussed on what appeared to be happening in New South Wales.

This article draws upon contemporary concerns pertaining to the Murray-Darling Basin to illustrate the importance of water issues in the context of rurality and criminality. Examining the issues from a green criminology perspective, the article considers aspects of rural cultures, communities and corporations and the intersecting knowledges, interests and power groupings that shape the social construction of and responses to water theft. 


\section{Figure 1: Map of the Murray Darkling Basin in context ${ }^{1}$}

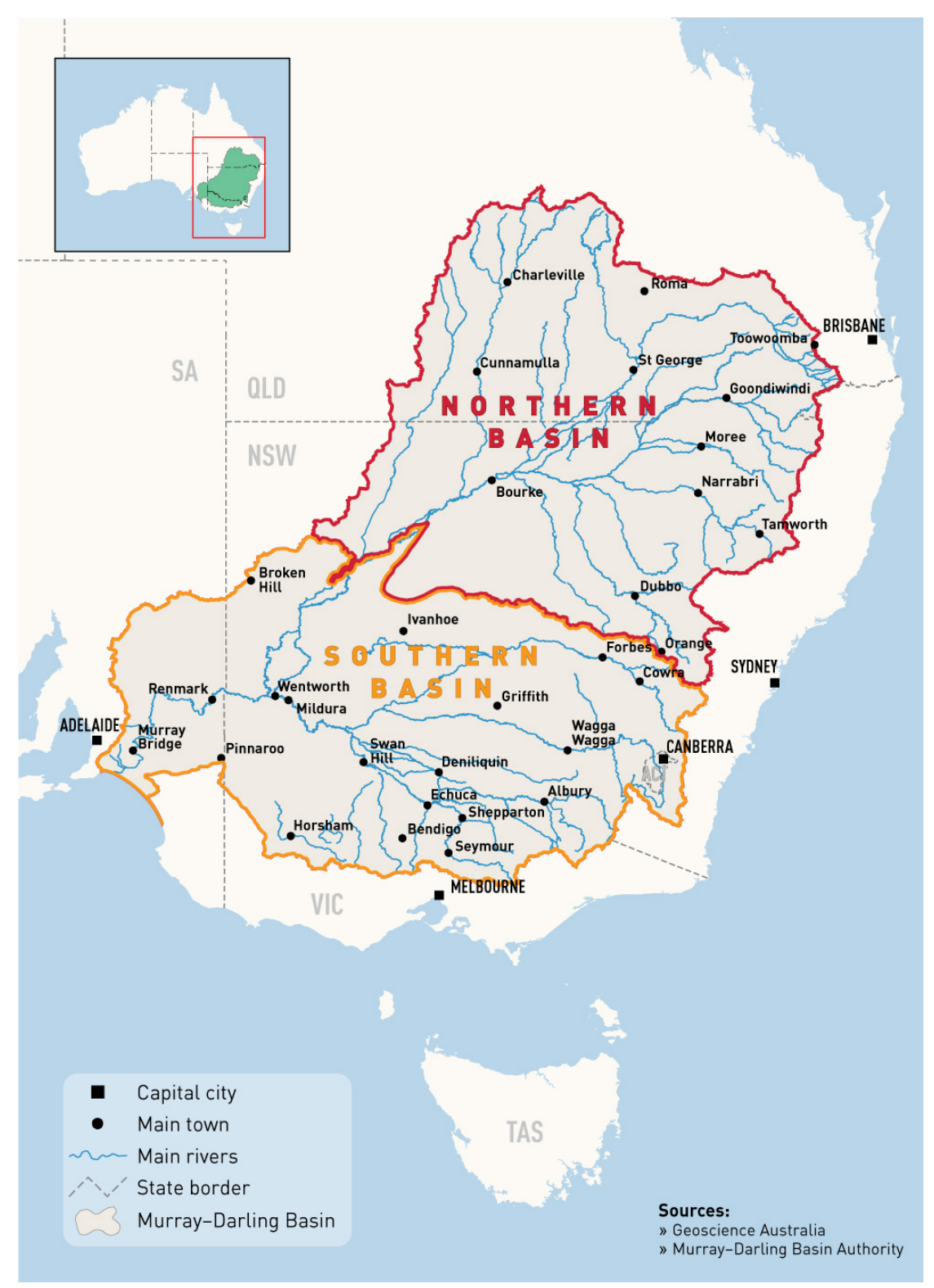

Green criminology refers to criminological research and scholarship comprised of distinct theoretical approaches that collectively deal with environmental and animal rights issues (Goyes et al., 2017; Hall, 2015; Lynch et al., 2017; Nurse, 2016; South \& Brisman, 2013; White \& Heckenberg, 2014). As a whole, green criminology focuses on the nature and dynamics of environmental crimes and harms (that may incorporate wider definitions of crime than that provided in strictly legal definitions); environmental laws (including enforcement, prosecution and sentencing practices); environmental regulation (systems of administrative, civil and criminal law that are designed to manage, protect and preserve specified environments and species, and to manage the negative consequences of particular industrial processes); and eco-justice (the valuing of and respect for humans, ecosystems, non-human animals, and plants).

A fundamental premise of green criminology is that environmental crime needs to be defined and studied in relation to harm, and not solely on the basis of legal definitions. Much 


\section{Water theft in rural contexts - White}

attention is directed at how, where and why natural resources are used, and the impacts of this on the wider environment. This includes consideration of:

- natural resource extraction and, in particular, what is being extracted, how, and for what purposes (for example, trees from forests, water from rivers, fish from oceans);

- contamination related to natural resources (such as, for example, pollution of streams and creeks from factories) and the threat posed by stockpiles of toxic and hazardous materials (for example, mine tailings dams); and

- transformations in nature that have potentially harmful consequences (for example, clearing land for flex crops [multiple-use plants such as palm oil] and building dams, both of which affect water flow and land use).

As the in-bracket examples illustrate, water is at the centre of many of these natural environment issues.

The significance of these issues cannot be understated. In the context of rapid climate change, for instance, freshwater resources stand out as one of the vital pinch-points arising from global warming. These resources are under threat worldwide due to the shrinking of glaciers and polar ice sheets, extended periods of drought, human diversion and pollution of waterways, flooding, saltwater contamination due to sea level rise, and expanding consumer (resident and business) demands (IPCC, 2014; US Global Change Research Program, 2018). For people in regional in-land areas of Australia, water is of paramount importance.

The article begins by providing a brief overview of water crimes. This is followed by consideration of matters pertaining directly to the Murray-Darling Basin, in particular allegations of water theft. Why and how this theft occurs is discussed in the light of considerations of geography, culture and regulatory systems.

\section{Water crimes in Australia}

Australia is 'recognised as the world's driest inhabited continent' [and] 'despite occupying 5.6 per cent of the world's land mass, Australia receives little more than one per cent of the world's available freshwater resources' (Lehane, 2014, p. 1). Access to freshwater varies considerably across the continent; widespread drought is frequent, as is the occurrence of flooding in some parts of the country.

Pressures on water supply, its quantity and quality, are causing major consternation within Australia. This will only intensify in the coming years, given global warming and climate change, and the impact of drought and intense weather events (Steffen, Dean \& Rice, 2019). Recent mass fish deaths in the lower Darling River, involving millions of fish, were attributed to 'exceptional climatic conditions, unparalleled in the observed climate record' according to a preliminary report commissioned by the federal government (Sullivan, 2019, p. 1). But it is not only temperature rise that is perceived as a problem.

The lack of environmental flows of water has also been attributed to hundreds of billions of litres of water that has gone missing from the Murray-Darling Basin (Carbonell, Iggulden \& Davies, 2019). Issues of irrigation efficiency, private interests and government regulation of the river system seem to be intertwined in ways that are to the detriment of the environment, downstream local communities, and non-human animals and plants dependent 
upon the system. There is something fishy going on, and it is not simply what is left in the dry riverbeds.

In general, crimes such as water theft are not necessarily new phenomena for Australia but current climatic conditions, a history of overuse, and variable source replenishment have brought the problem and consequences of unauthorised extraction and use of water to the national forefront. The introduction of water restrictions and stricter approaches to managing Australia's water resources, most prominently the Murray-Darling Basin, potentially (and probably) increases the temptation to take water that one is not entitled to. Water theft covers not only taking from natural water courses, but also the stealing of harnessed or piped water (Barclay \& Bartel, 2015). The latter takes in offences of actual theft, breach of extraction conditions and construction of works to illegally take water, tampering with meters to relay false readings, and contravening declared water restrictions.

An Australian study on the perspectives of farmers by Barclay and Bartel (2015) provides insight into how fresh water is being 'stolen' through diversion, despoiling and depletion, on the drivers or incentives for water theft, issues of non-compliance, and how water theft results in availability and access injustices. Drawing upon this and other literature a range of specific transgressions can be identified: for example, water theft, water contamination, waterway diversion, and over-extraction of coastal groundwater, all of which have significant social and ecological impacts (Barclay \& Bartel, 2015; Poff \& Zimmerman, 2010; Vörösmarty et al., 2010; Narayan et al., 2007; Werner, 2010; Greiner et al., 2016, p. 27). Other matters warranting further consideration include the risks and threats of waterrelated terrorism (for example, the intentional poisoning of freshwater supply), and the waterrelated consequences of poorly regulated storage of toxic chemicals and hazardous waste (which are vulnerable to being swept up in flood waters and thereby pollute freshwater systems).

Water theft, among other water crimes, results in injustices related to the availability and access of fresh water. Until recently, however, for all its importance to social, economic and ecological health and wellbeing, there has been relatively little criminological interest in water issues as such. One exception to this is the growing body of work in green criminology that has provided extended examination of water issues in regards pollution, access, ownership, management, and security (White, 1998; 2003; Johnson et al., 2016; Brisman et al., 2016; 2018). In the light of what we presently know about water crimes, and the potential drivers that will most likely see an increase in these types of crimes, there is clear rationale for immediate and ongoing research in this area.

\section{Exploitation and scarcity}

Who is most negatively affected by resource extraction, including the use and extraction of water, is partly a function of what can be exploited, where it is located, and how much resistance is likely to be encountered. This is also at the heart of the link between resource extraction and corruption (White, 2017). The mega-mining developments of contemporary Australia, for example, are affecting a wide spectrum of people, ranging from particular Indigenous communities (for example, in the Northern Territory) through to the farmers of the Hunter Valley in New South Wales (pastoralists as well as wine-makers), and much of this negative impact pertains to water use (both extraction and contamination). 


\section{Water theft in rural contexts - White}

The presence and activities of the large corporate-driven industries, including agribusinesses such as cotton growers, equate to the use of oceans, mountains, rivers, trees and lands for private profit (Stretesky, Long \& Lynch, 2014). This generally involves the commodification of both nature and human labour as each is regarded first and foremost in terms of the buyer-seller nexus (Johnson et al., 2015). Three decades of neo-liberalism have seen the further intense exploitation of nature (ecosystems, and abiotic or non-living entities such as rivers), the non-human (animals, plants), and humans (workers and consumers), with little restraint. The frequent result of this exploitation is human-induced scarcity. This is as true for water (which has a use-value in and of itself that makes it highly exchangeable) as it is for other types of resource-based commodities. It also pertains to the use of water in adding value to other forms of commodity (such as cotton).

Shortages of food, water and non-renewable energy sources, and the search for new places where resource extraction can continue, ensure the continuing value of these in the global marketplace (Klare, 2012). The continuation of extractive activities contributes to even more ruthless exploitation of rapidly vanishing natural resources, as well as the further diminishment of air, soil and water quality, thereby exacerbating the competition by individuals, groups and nations for what is left.

Scarcity is tied to the over-exploitation of natural resources. It is also increasingly linked to the consequences of global warming (IPCC, 2014; US Global Change Research Program, 2018). The choices ingrained in environmental exploitation stem from systemic imperatives to exploit the planetary environment for production of commodities for human use. There are measureable bio-physical and socio-economic consequences arising from the various sources of threat and damage to the environment, that include pollution, resource degradation, biodiversity loss and climate change (South, 2012; White, 2018a). Destructive activity includes the disproportionate and unsustainable taking of water (Brisman et al., 2018). Scarcity can arise from depletion or degradation of the resource (supply), increased demand for it (demand), and unequal distribution and/or resource capture (structural scarcity) (Homer-Dixon, 1999). Certainly water scarcity ticks all of these boxes.

Going hand-in-hand with scarcity, securitisation refers to the efforts of the powerful to secure financial rewards by controlling access to and use of natural resources. This may be rationalised or justified under the rubric of the 'national interest' or the 'free market'. But whether through fair means (that is, legal) or foul (that is, illegal and criminal), the net result is essentially the same - the exploitation of nature in ways that favour the interests of the powerful.

Gaining unfair advantage, protecting specific sectoral interests and over-riding existing environmental regulations are all features of moral and direct corruption associated with the exploitation of natural resources including water (White, 2017). Yet, the notion of environmental insecurity ('we need to protect our national interests'), linked to the notion of the need for jobs ('the winners are local communities'), provides a powerful platform upon which the legitimacy of such securitisation of nature is constructed.

\section{Water theft from the Murray-Darling Basin}

The management of water, especially in cross-jurisdictional contexts, is always going to be complicated. For large water systems such as the Murray-Darling Basin the complexities are magnified as they involve dynamics related to specific geographical and 
political interests; matters of science, data management and communication; and ongoing tensions arising from balancing the needs of the environment and consumptive users (Marshall, Connell \& Taylor, 2013; Docker \& Robinson, 2014; Hart, 2016a; 2016b). From the specific point of view of green criminology, the illicit taking of water from the MurrayDarling Basin can be analysed across several key dimensions.

\section{Criminalisation and the extent and seriousness of harm}

The concept of harm is at the heart of green criminology conceptualisations. It does not just refer to legal definitions of 'crime' but includes 'social harm' definitions (in part because the law makers - influenced by or part of powerful groups such as nation-states and corporations - pass laws that favour themselves even where harm is an outcome). The notion of malem in se refers to harms or crimes in themselves, that is, very serious harms. On the other hand, malem prohibita refers to harms defined as such because they involve breaches of law or regulation (White, 2011).

This distinction is important (initially) since the 'taking of water from the river' is generally not in itself criminalised or a crime in its own right. Rather, the status of this activity is defined by whether it is subject to legal restrictions or licensing provisions. This means that it is not 'theft' unless it has been expressly prohibited and/or involves breach of license conditions. Green criminologists, however, may question the extent to which a license allows so much water to be taken that it constitutes an environmental harm. That is, the use of ecological criteria instead of official government metrics (involving stipulated maxima for water use) may give rise to different answers to the question 'is this harmful'? Nonetheless, as water use is generally considered malem prohibita, this also has implications for how water-related harms are responded to by the public and state officials.

Harms such as the unauthorised taking of water may be construed as:

(1) breaking of rules, and the response might simply be a 'warning';

(2) illegal behaviour, for example, for breaching a license conditions, and for which the response might be an administrative fine or civil order to desist from particular actions; and

(3) a criminal offence, involving breach of criminal law and warranting penalties such as fines and imprisonment.

In the case of the water use, key issues include if and under what circumstances it is framed in terms of 'harm' and what the presumed harm is; if and when the harm might be considered 'theft'; and if so, whether this is seen as morally bad, illegal or criminal. To some extent, this demands attention to ways in which the harm is defined, measured and presented. Harm to what or who is a consideration (for instance, individual farms, specific human communities, non-human animals, ecosystems), as is whether something is (also) harmful because it represents a flouting of rules, licenses and regulations, thereby undermining the overarching system of laws and regulation. Not everyone views unauthorised taking of water the same way. In part, views are shaped by circumstance and context. 


\section{Water theft in rural contexts - White}

\section{Rural folk norms and crimes}

The notion of 'folk crime' refers to offences that are generally perceived by perpetrators and other members of their community as not being particularly criminal, offensive, harmful or dangerous. Wilson (1983) outlines the main elements of folk crime:

- The usual links between morality and law may be broken, depriving the extended criminal law of its moral sanctions;

- Strong inducements may exist for the public at large or significant segments of it to violate the law;

- Control organisations may become overwhelmed by the non-traditional task; and

- Law violation may become a chronic problem in which the resources of the legal system face a perpetual burden that diminishes the ability of the system to respond to its traditional goals.

A central idea is that 'we all do it' and so those caught doing it are not necessarily deemed 'evil' or 'unworthy' enough to warrant suffering unpleasant penalties and/or the stigma attached to ordinary criminal sanctions. Some common examples of folk crimes include fishing offences (fishing in marine parks or out-of-season) and abalone poaching (taking abalone for personal use). Each of these activities may be wrapped up in local customs and traditions that, in turn, justify the bypassing of official legal constraints.

Folk crimes frequently present as embedded facets of everyday life that can and do involve great social and ecological harms (Gibbons, 1972). Such crimes are frequently committed repeatedly by the same offenders, who are well known in the offenders' community, and do not impair the offenders' public identity as respectable and law-abiding citizens (Wilson, 1983). In the public eye, folk crimes may not be seen as causing harm that is of significant importance (Muth, 1998). Alternatively, they may be rationalised on the basis of presumptions of 'local needs and rights', as discussed below.

Rural folk crime has generally been related to hunting and gaming laws, wood burning and land clearance, and nature harvesting of items such as mushrooms, abalone and flowers. In relation to farmers, it has been used to reference activities that encompass violations of government regulations related to both flora and fauna, for example, as instances of localised expressions of oppositional behaviours by agriculturalists in response to state-imposed laws (Donnermeyer, Scott \& Barclay, 2013). Discussion of poaching has likewise considered aspects of illegal hunting as forms of folk crime linked to tradition or culture and as resistance to conservation policy that is seen to be unfair and lacking in legitimacy (von Essen et al., 2014; 2015).

The taking of water, especially by farmers and especially during periods of drought, can perhaps also be considered such a crime. The important thing from the point of view of folk crime is that such activities are considered 'legitimate' according to local customs and traditions. Support for such practices by local elites and at the community level means that criminalisation-in-practice is rarer than in those circumstances where the participants occupy more marginalised social positions - unless it is the whole community that is feeling marginalised and under threat.

The ravaging of nature frequently takes place with the consent of its beneficiaries, among which are the general populaces of rural areas of Australia. Or at least this is one 
possible narrative in regards the taking of water 'against the rules'. The normalisation of deviance based upon notions of contingent use does not only involve potential denial of harm (that is, ignoring the long-term consequences of water taking for the life of a river and its ecosystem for the sake of today's survival needs). It may also involve aspects of 'moral ecology' (Jacoby, 2001). Typically, a moral ecology exists in regards specific types of folk crime, and those who engage in such crimes, in particular relating to both 'rationalisations' (certain techniques of neutralisation) and destructive versus benign traditional folk practices (the morality of extraction and usage). To put it differently, certain informal rules guide what is allowable and what is not when it comes to the natural surrounds. This could be in the order of 'never kill anything that you do not need' through to not disturbing fish, fowl or forest creatures when in the midst of breeding season (Jacoby, 2001, p. 24).

Jacoby (2001) describes how taking wood from a state forest was not necessarily seen by local residents as a 'crime' but rather as quite legitimate if done for the purposes of subsistence (such as for fire wood, buildings materials and the like). This 'theft' of trees from state forests (i.e., protected conservation areas) was seen to be perfectly okay if not done for the purposes of future market gain (as with selling firewood). Moreover, local people in the Adirondacks in New York state also distinguished between different types of wood according to subsistence and market activities, only taking the more acceptable nonmarketable hardwoods for their own personal uses.

An important area for consideration, therefore, is how the moral ecology of water use is constructed by different users (e.g., small farms, agribusinesses, residents, Indigenous people) in different geographical locations (on the continuum river origins to end of the river).

For now, the main point is that water taking is not intrinsically considered 'bad' by stakeholders close to the scene of the alleged crime - interpretation of its use is highly contingent upon context. This means that when and why the 'stealing' of water is considered morally wrong (regardless of legal status) forms part of the analysis of environmental harm and its social construction and representation.

For some, the language is one of survival - farmers who are interviewed on television about the present-day drought in Australia will often respond with comments to the effect that 'our community depends upon this water, and we need it now'. This is an assertion of propriety rights based upon present need and geographical location (it is here, we need it, we will use it). The idea is that locals will protect their own local interests. This attitude also feeds into State-rights type of discourse, in which for example, the interests of New South Wales are pitted against the interests of South Australia. But this whole process of assertion simultaneously involves denial of harm, that is, ignoring the long-term consequences of water taking for the life of a river and its eco-system, all for the sake of today's survival needs. Death of rivers will eventually come due to over-exploitation for local purposes - but slowly (but this, too, depends upon extraneous factors such as the dynamics of climate disruption).

\section{Environmental regulation and social interests}

Regulation involves efforts to ensure compliance by benign means (for example, through education, monitoring, training and encouragement) as well as through direct enforcement (for example, the imposition of sanctions). The seriousness of harm is tiered from low to high, and each tier brings with it different potential responses on the part of the 


\section{Water theft in rural contexts - White}

state. The responses include use of administrative (e.g., on-the-spot fine, warnings), civil (e.g., cease and desist orders, compensation, fines) and criminal measures (e.g., fines, imprisonment).

There are many tools in the regulators toolkit that can be drawn upon (depending upon the seriousness of the alleged breaches of regulations and laws). Investigation and intervention are vital to good environmental regulatory practice. Knowing when and how to use regulatory tools (including the level and combinations of sanction - administrative, civil and criminal) is crucial to ensuring good environmental outcomes. In a similar vein, political will to regulate diligently and in the public interest is important (this has implications for priorities and resource allocation within an agency), as is the problem of 'regulatory capture' (where the regulator ends up working hand-in-hand with the industry, to the industry's interests).

Bricknell (2010) points out that formally establishing incidents of water theft comes from three forms of monitoring activity. The first focuses on compliance auditing of water licenses, involving site visits and in which works and equipment are inspected (and tested) and metering and water usage records are reviewed. Compliance auditing is supplemented by surveillance comprising (depending on jurisdiction) aerial, ground and river surveys, combined with aerial photography and the use of satellite images. Surveillance is used to detect unauthorised works, irregular flows and other signs of illegal water diversion. Reports of alleged breaches from the public, local councils or state utilities and other government departments represent the third method whereby regulators are alerted to possible water theft (Bricknell, 2010).

The difficulties now associated with preventing water theft are akin to those for native vegetation clearance. While the regulation of water use has been in place much longer than it has for native vegetation clearance, bulk water users up until very recently had what has been described as rather generous allowances regarding the where from, what for and how much. Now these same users are being told that allocations are to be reduced, old entitlements reviewed and new entitlements put on hold and construction of works for extraction and diversion purposes to be more vigorously monitored. In other words, a culture of entitlement is being challenged by a new set of rules and a level of scrutiny not previously experienced. For this reason, like native vegetation clearance, it is assumed that the scale of the crime is probably a lot larger than officially reported and comprises a significant proportion of intentional non-compliance (Bricknell, 2010). Moreover, under such conditions, there is greater likelihood of water theft being construed as mere folk crime rather than serious transgression.

When it comes to water compliance and enforcement, Queensland research suggests that most water users are compliant with water rules principally because of strong spontaneous compliance, which is chiefly grounded in the belief that the rules are required to safeguard a common water resource (Greiner et al., 2016). The study suggests, however, that some water users may be intentionally taking water in excess of license conditions in order to maximise business profitability. Non-compliance is underpinned by perceived low probability of successful prosecution and a comparatively small penalty if a breach can indeed be proven. From a water management perspective, the findings highlight the critical role of ongoing education and communication efforts for maintaining high levels of spontaneous compliance. Stronger deterrents may be needed to address the intentional unlawful taking of water in the given context, including increasing penalties to ensure fines 
result in a net cost to offenders and reduction of water entitlements of repeat offenders. Improvements in water administrative processes can minimise the likelihood of offenders escaping a penalty (Greiner et al., 2016, p. 26).

Another dimension of water-related regulation is the potential for corruption involving government officials. It is important to gauge whether or not corruption is evident and to what extent and what forms it takes if it does occur. This may involve informal and selective non-enforcement of water-use rules and laws (based upon friendship networks and local area dynamics) through to bribery and associated corrupt practices.

In the specific case of the allegations made in the Four Corners program, official inquiries have established major problems in the existing regulatory apparatus, including record-keeping pertaining to compliance and enforcement (Matthews, 2017; Murray-Darling Basin Authority, 2017; New South Wales Ombudsman, 2018). Commenting that the 'industry's "social license to irrigate" is at stake', Matthews $(2017$, p. 5) found that waterrelated compliance and enforcement arrangements in New South Wales have been ineffectual and require significant and urgent improvement. After independent investigation into the issues raised by the $\mathrm{ABC}$ (outlined in the introduction), Mathews $(2017, \mathrm{p} .4)$ found that:

- The overall standard of NSW compliance and enforcement work has been poor.

- Arrangements for metering, monitoring and measurement of water extractions, especially in the Barwon-Darling river system, are not at the standard required for sound water management and expected by the community.

- Certain individual cases of alleged non-compliance have remained unresolved for far too long.

- There is little transparency to members of the public of water regulation arrangements in NSW, including the compliance and enforcement arrangements which should underpin public confidence.

In a nutshell, according to Matthews (2017, p. 4), a 'systemic fix' is required.

Compounding the difficulties is the sheer scale of the landmass and size of the stakeholder community needing to be integrated into a coherent regulatory scheme. There are a number of jurisdictions involved: South Australia; Victoria; New South Wales;

Queensland; the Australian Capital Territory; and the federal government. At the States level, there is considerable variation in compliance and enforcement systems, compliance resourcing and transparency. There are also differences in the availability and use of administrative, civil and criminal penalties and sanctions (Murray-Darling Basin Authority, 2017 , p. 22). The same holds for enforcement activity. In 2016-17 for example:

NSW issued 44 warning letters and notices, Queensland 14, South Australia 355, Victoria 562, and the ACT 1. For advisory letters, the numbers were 122 in NSW, Queensland issued 12, Victoria 412, South Australia 9765 (the latter number is high because it includes pre-emptive letters associated with introducing self-reading of meters), with no advisory letters issued in the ACT. ... Across all Basin states, the end result of compliance activity is a very small number of prosecutions. In 2016-17 there were no prosecutions in NSW and Queensland, and six in the other states (MurrayDarling Basin Authority, 2017, p. 13). 


\section{Water theft in rural contexts - White}

To put these figures into context, it would be interesting to investigate prosecutions by other enforcement bodies such as environmental protection agencies and relevant environment courts (and particularly specialist environment courts in New South Wales, South Australia and Queensland) on water-related matters, including breaches of law.

\section{Interpreting the issues}

From a green criminology perspective, attention is drawn to how seriously harm is construed in regulatory forums and political debate, and the kinds of sanctions that are utilised to respond to such harms. Stealing water is considered a major offence from a green criminology viewpoint - yet, the mobilisation of state machinery and criminal law may belie its status as either serious or warranting strong remedy.

If authorities respond with 'light touch' regulation or minor sanctions (if any), then this may indicate one of several things. It could be that the concern is more with regulatory systems, procedures and efficiencies than with the crime itself; or issues of corruption and omission in regards duty of care; or issues of responsibility and liability.

How the state (and media) responds to water theft is usually explained through the lens of political economy in green criminology (Stretesky et al., 2014; Brisman et al., 2018). The first part of the phrase political economy refers to an emphasis on examining the role and activities (including failures to act) of nation-states (or governments at lower levels) in facilitating and/or providing the conditions under which environmental destruction and harm occurs. This is about public policy and the dynamics of state intervention. The second and often intertwined consideration is the nature of large corporations, which wield considerable financial and political power. Profit-making for private interests is frequently supported by governments in a variety of instrumental, financial and policy-oriented ways.

Environmentally harmful economic activity in countries such as Australia tends to congeal around two key areas of concern - resource extraction (such as mining, forestry and fishing; and water for sale); and contamination (the pollution of land, air and water associated with production and consumption activities) (see also Stretesky et al., 2014). At the heart of these activities lies the quest to increase and augment private profit, in regards specific companies but also for the benefits that accrue to individual corporate stakeholders such as investors, shareholders and directors. Critical green criminologists argue that this focus is generally destructive and uncaring of environments (unless there is money to be made in preserving selected terrain, non-human animals, plants or water systems). Water theft by big companies fits within this general framework of critique (Brisman et al., 2018).

So, too, does the commodification of nature (White, 2018a). That is, nature (and human labour) is treated as a 'thing' that only has worth insofar as it can be exchanged on the market. Transformations of nature involve the commodification of nature such that the 'usevalue' (its intrinsic usefulness), for example of water, is transformed into 'exchange-value' (its market value). For instance, fresh water is no longer free and accessible but becomes a commodity that is sold to people. Natural resource management therefore becomes centred on regulation of those paying-for-the-benefit (as reflected in licenses) as well as, occasionally, those who are not ('theft' in the traditional sense, since they do not have a license). This may well be justified on the grounds of preserving the quantity and quality of the resource. Yet, it simultaneously privileges the license holder as someone worthy of what 
Matthews (2017, p. 35) describes as a "customer-focused service orientation". This, of course, puts the regulator in a rather invidious position.

The intrusion of corporate forms of valuation and exploitation into all spheres of life has been described as the corporate colonisation of nature (South, 2007). Government policies set the context within which contemporary neoliberal practices and ideologies flourish. The emphasis here is on 'the market' as determiner of who gets what, and on the individual taking responsibility for their opportunities and life chances. The environment is viewed as part of the national economic calculus, rather than as having intrinsic importance. Resource extraction companies, such as big oil, coal and gas companies - and in the present case, large cotton growers in the Murray-Darling Basin - tend to receive privileged support from governments regardless of the damage they cause to specific environments or the contributions they make to global warming (Kramer \& Michalowski, 2012; Kramer, 2013; Ruggerio \& South, 2013). Public policy is framed in terms of supporting big business (through tax breaks and via policies that allow continued water extraction to occur), and corporations in turn are generous contributors to the coffers of mainstream political parties.

Both states and companies regularly engage in techniques of neutralisation whereby they decry their critics, deny the extent and nature of environmental harm, and excuse themselves from accountability for environmental destruction accompanying economic enterprise (Brisman, 2013). This case was no exception. At the time of the Four Corners broadcast, the then federal water minister Barnaby Joyce refused calls for the federal government to step in and investigate. Instead, he placed the responsibility back on state governments. Moreover, he accused Four Corners of taking part in a campaign to take more water from irrigators. The messenger was the target; the transgressors portrayed as victims caught in a web of journalistic vilification.

By contrast, from a green criminology perspective, the destruction of the environment in ways that adversely affect humans, ecosystems, and non-human species can be conceptualised, criminologically, as a specific type of crime. Ecocide describes an attempt to criminalise human activities that destroy and diminish the wellbeing and health of ecosystems and species within these, including humans (Higgins, 2012; see also Higgins, Short \& South, 2013). Where this occurs as a result of human agency, then it is argued that a crime has occurred. The diminishment and exploitation of water eco-systems would seem to fit into this category of crime.

So, too, does corruption associated with regulatory processes and outcomes (White, 2017). Corruption relating to the environment can be interpreted as implying both moral corruption (involving the undermining of trust and respect for established governmental processes and institutional practices, as guided by democratic over-sight) and/or direct corruption (involving direct breaches of criminal laws, facilitated by government officials and non-government actors). At a concrete level, the actions of governments and businesses frequently privilege the rights and interests of the powerful over the public interest. Sometimes this takes the form of direct state-corporate collusion (state-corporate crime); in other instances, it involves manoeuvring by government officials or company executives to evade the normal operating rules of planning, development and environmental impact assessment. Certainly the Four Corners program suggested this when it accused the top regulator, Gavin Hanlon, of helping lobbyists who were campaigning against the MurrayDarling Basin plan (see also Matthews, 2017). 


\section{Water theft in rural contexts - White}

\section{The politics of victimisation}

Another issue worthy of further examination is how victimisation is constructed. For example, in popular and political discourse it is often 'States' that are presented as 'victim'. State-speak in this instance is usually a synonym for 'people of South Australia' (which itself is problematic - since the harm is to some more than others usually). Breaking this down, the key recipients of the harm are the growers along the river, the residents further down the stream, and the wildlife and plants that are dying at the mouth of the river where it flows into the ocean. "South Australia" as 'victim', therefore, is shorthand for geographically specific harms, affecting a variety of actors.

The framing of the problem this way points to other 'States' (namely Queensland, and especially New South Wales) as the main culprits (or 'offenders'). This reduces the issues to one of States-rights and still does not get to the heart of several other salient issues - in this case, the disproportionate use of water by large agribusinesses in the Murray-Darling; and the lack of attention to the ecological criteria needed to assess adequate water flow and distributions.

The question also poses interesting issues from the point of view of state as criminal (e.g., state-corporate crime involving certain acts and omissions); and state as victim (although this usually takes the form of terrorism, corruption or foreign interference in governmental processes). There are multiple dimensions to this particular construction of victimisation (that is, states as victims). Green criminology would accept that it needs to be studied, but it needs to be done critically. To some extent, such framing tends to distract from other framings and to simultaneously tap into a 'nationalistic' rhetoric (albeit at State-level) that obliterates any kind of class, gender, ethnic or racial analysis (including the place of Indigenous people and communities in this whole debate) and social differences.

Consider this. For the past four hundred years on a global scale the extraction of natural resources has fundamentally been a project of displacement and destruction. Indeed, the history of the modern world is based precisely upon resource colonisation, a phenomenon that has negatively impacted many different Indigenous peoples in places such as South America, North America, and Australasia, as well as the native inhabitants of Africa, Asia and beyond (White, 2011). Across the planet, the prior ownership rights, interests and knowledge of Indigenous inhabitants were treated as irrelevant by the European invaders. People who for thousands of years had lived in harmony with nature (that is, through intrinsically adopting ecologically sustainable practices), including in some of the most humanly inhospitable places in the world (such as Arctic tundra and sand deserts), were subjected to dispossession, displacement and destruction of their communities. These processes are mirrored in the contemporary exploitation of natural resources worldwide that continues to hugely affect Indigenous communities (Gedicks, 2005; Klare, 2012; Short, 2016).

So where do Indigenous people fit in the present 'water theft' scenario? This is a big and largely unanswered question that rarely attracts prominent attention in public debates surrounding the Murray-Darling Basin. Given that rivers are being granted personhood in New Zealand under the stewardship of local Indigenous groups, the contrast with Australia could not be more startling and revealing (White, 2018b). 
Critical green criminology also tends to view environmental harm in terms of ecojustice in accordance with three broad approaches to justice, each with its specific conceptions of what is harmful (White, 2013). In mainstream politics, very often the issues are framed anthropocentrically (they are human-centred). Green criminology and eco-justice frameworks speak of harm in relation to humans, ecosystems, non-human animals, and plants. There is concern with both biotic (living) and abiotic (non-living) parts of the natural world, and non-human environmental entities include rivers and mountains as well as birds and horses. Water theft, particularly in great quantities, impacts across each of these domains. This can be measured ecologically as well as socially. Indeed, if we wanted to, we could employ the tools of environmental and social impact assessment to gauge the degree and nature of the harms.

Attention is now being paid by Murray-Darling Basin authorities to the protection of environmental water, but this is relatively under-developed as of yet. It has been pointed out that "[1] eaving water in rivers at volumes, times and locations to improve the health of the system is a relatively new concept. The rules for running the rivers need to adapt in order to allow both extractive use and environmental protection" (Murray-Darling Basin Authority, 2017 , p. 15). Where the interests of the river(s) fit into debate over water theft certainly warrants greater attention.

\section{Conclusion}

From a green criminology perspective, analysis and interpretation of water theft requires concerted efforts to research who is using water, how and for what purposes, and the impacts of water-taking on humans as well as non-human environmental entities such as rivers, trees, fish and kangaroos. Information and data pertaining to these questions is vital in exposing the nature of environmental harm, and the consequences of such harm for different stakeholders and groupings reliant upon water from the Murray-Darling Basin. The geographical location of water theft is integral to the dynamics and nature of the harms committed, and the response of both governments and residents to the crime.

Issues pertaining to water crimes in rural contexts such as described in this article are not going to go away, nor are they easily solved. Water theft is a significant problem and more water theft in the future is inevitable given climate change. Diverse interests exist over water use, so the public interest and good environmental outcomes must be prioritised for the sake of the longer-term health of rivers and the communities that live alongside them. The rights and interests of non-human environmental entities must be taken into account in any strategic response and policy initiative - this refers to the health of the river, local ecosystems, fish populations, plants, and non-human animals that rely upon freshwater systems. The viability of 'the bush' in dry and drought-prone places such as Australia ultimately depends upon protecting its water - the essence of life.

\section{Endnote}

${ }^{1}$ Map of Murray Darling Basin, sourced from the Murray Darling Basin Authority, https://www.mdba.gov.au/discover-basin/landscape/geography 


\section{Water theft in rural contexts - White}

\section{References}

ABC Four Corners. (2017, 24 July). Pumped: Who's benefitting from the billions spent on the Murray-Darling. Retrieved 10/1/2019 from www.abc.net.au/4corners/pumped/8727826. Accessed 10 January 2019

Barclay, E. and Bartel, R. (2015). Defining environmental crime: The perspective of farmers. Journal of Rural Studies, 39, 188-198. https://doi.org/10.1016/j.jrurstud.2015.01.007

Bricknell, S. (2010). Environmental crime in Australia. Research and public policy series no. 109. Canberra, ACT: Australian Institute of Criminology. Retrieved from https://aic.gov.au/publications/rpp/rpp109

Brisman, A. (2013). The violence of silence: Some reflections on access to information, public participation in decision-making, and access to justice in matters concerning the environment. Crime, Law and Social Change, 59(3), 291-303. https://doi.org/10.1007/s10611-013-9416-3

Brisman, A., McClanahan, B., South, N. and Walters, R. (2018). Water, crime and security in the twenty-first century: Too dirty, too much, too little. London, UK: Palgrave. https://doi.org/10.1057/978-1-137-52986-2

Brisman, A., McClanahan, W. and South, N. (2016). Water security, crime and conflict. In M. Tonry (Ed.), Oxford Handbooks in Criminology and Criminal Justice. Oxford, UK: Oxford University Press. https://doi.org/10.1093/oxfordhb/9780199935383.013.86

Carbonell, R., Iggulden, T. and Davies, J. (2019, 6 March). Murray-Darling Basin could be missing billions of litres of water, study claims. ABC Rural NEWS.

Craik, W. (2018). Report of the independent reviewer: Basin compliance compact to the Murray-Darling Basin Ministerial Council. Canberra, ACT: Murray-Darling Basin Authority.

Docker, B. and Robinson, I. (2014). Environmental water management in Australia: Experience from the Murray-Darling Basin. International Journal of Water Resources Development, 30(1), 164-177. https://doi.org/10.1080/07900627.2013.792039

Donnermeyer, J., Scott, J. and Barclay, E. (2013). How rural criminology informs critical thinking in criminology. International Journal for Crime, Justice and Social Democracy, 2(3), 69-91. https://doi.org/10.5204/ijcjsd.v2i3.122

Gedicks, A. (2005). Resource wars against native peoples. In R. Bullard (Ed.), The quest for environmental justice: Human rights and the politics of pollution (chapter 8). San Francisco, CA: Sierra Club Books.

Gibbons, D. (1972). Crime in the hinterland. Criminology, 10, 177-191. https://doi.org/10.1111/j.1745-9125.1972.tb00552.x 
Goyes, D., Mol, H., Brisman, A. and South, N. (2017). Environmental crime in Latin America: The theft of nature and the poisoning of the land. London, UK: Palgrave. https://doi.org/10.1057/978-1-137-55705-6

Greiner, R., Fernandes, L., McCartney, F. and Durante, J. (2016). Reasons why some irrigation water users fail to comply with water use regulations: A case study from Queensland. Land Use Policy, 51, 26-40.

https://doi.org/10.1016/j.landusepol.2015.10.019

Hall, M. (2015). Exploring green crime: Introducing the legal, social and criminological contexts of environmental harm. London, UK: Palgrave.

Hart, B. (2016a). The Australian Murray-Darling Basin Plan: Challenges in its implementation (Part 1). International Journal of Water Resources Development, 32(6), 819-834. https://doi.org/10.1080/07900627.2015.1083847

Hart, B. (2016b). The Australian Murray-Darling Basin Plan: Challenges in its implementation (Part 2). International Journal of Water Resources Development, 32(6), 835-852. https://doi.org/10.1080/07900627.2015.1084494

Higgins, P. (2012). Earth is our business: Changing the rules of the game. London, UK: Shepheard-Walwyn Publishers.

Higgins, P., Short, D. and South, N. (2013). Protecting the planet: A proposal for a law of ecocide. Crime Law and Social Change, 59(3), 251-266.

https://doi.org/10.1007/s10611-013-9413-6

Homer-Dixon, T. (1999). Environment, scarcity, and violence. Princeton, NJ: Princeton University Press.

IPCC (Intergovernmental Panel on Climate Change). (2013, 27 September). Working Group I Contribution to the IPCC Fifth Assessment Report Climate Change 2013: The Physical Science Basis (Summary for Policymakers). Retrieved 2/11/2016 from http://www.ipcc.ch/pdf/assessment-report/ar5/wg1/WG1AR5_SPM_FINAL.pdf

IPCC (Intergovernmental Panel on Climate Change). (2014, 1 November). Climate Change 2014 Synthesis Report (Approved Summary for Policymakers) Retrieved 2/11/2016 from https://www.ipcc.ch/pdf/assessment-report/ar5/syr/AR5_SYR_FINAL_SPM.pdf

Jacoby, K. (2003). Crimes against nature: Squatters, poachers, thieves, and the hidden history of American conservation. Berkeley, CA: University of California Press.

Johnson, H., South, N. and Walters, R. (2015). The commodification and exploitation of fresh water: Property, human rights and green criminology. International Journal of Law, Crime and Justice, 44(2), 146-162. https://doi.org/10.1016/j.ijlcj.2015.07.003

Klare, M. (2012). The race for what's left: The global scramble for the world's last resources. New York, NY: Metropolitan Books, Henry Holt and Company.

Kramer, R. (2013). Carbon in the atmosphere and power in America: Climate change as state-corporate crime. Journal of Crime and Justice, 36(2), 153-170.

https://doi.org/10.1080/0735648X.2012.752252 


\section{Water theft in rural contexts - White}

Kramer, R. and Michalowski, R. (2012). Is global warming a state-corporate crime? In R. White (Ed.), Climate change from a criminological perspective (pp. 71-88). New York, NY: Springer. https://doi.org/10.1007/978-1-4614-3640-9_5

Lehane, S. (2014). Australia's water security Part 1: Water Resources, Global Food and Water Crisis Research Programme. Retrieved 24/1/2018 from http://www.futuredirections.org.au/publication/australia-s-water-security-part-1water-resources/

Lynch, M., Long, M., Stretesky, P. and Barrett, K. (2017). Green criminology: Crime, justice, and the environment. Oakland, CA: University of California Press.

Marshall, G., Connell, D. and Taylor, B. (2013). Australia's Murray-Darling Basin: A century of polycentric experiments in cross-border integration of water resources management. International Journal of Water Governance, 1, 197-218. https://doi.org/10.7564/13-IJWG17

Matthews, K. (2017). Independent investigation into NSW water management and compliance. Sydney, NSW: New South Wales Government.

Michalowski, R. and Kramer, R. (2006). State-corporate crime: Wrongdoing at the intersection of business and government. New Brunswick, NJ: Rutgers University Press.

Murray-Darling Basin Authority. (2017). The Murray-Darling Basin Water Compliance Review. Canberra, ACT: Murray-Darling Basin Authority.

Murray-Darling Basin Authority. (2019). A plan for the Murray-Darling Basin. Retrieved 31/10/2019 from www.Murray-Darling Basin Authority

Muth, R. (1998). The persistence of poaching in advanced industrial society: Meanings and Motivations. Society and Natural Resources: An International Journal, 11(1), 5-7. https://doi.org/10.1080/08941929809381057

Narayan, K., Schleeberger, C. and Bristow, K. (2007). Modelling seawater intrusion in the Burdekin Delta irrigation area, North Queensland, Australia. Agricultural Water Management, 89, 217-228. https://doi.org/10.1016/j.agwat.2007.01.008

Nurse, A. (2016). An introduction to green criminology and environmental justice. London, UK: Sage. https://doi.org/10.4135/9781473971899

Poff, N. and Zimmerman, J. (2010). Ecological responses to altered flow regimes: A literature review to inform the science and management of environmental flows. Freshwater Biology, 55, 194-205. https://doi.org/10.1111/j.1365-2427.2009.02272.x

Poljak, (2018, 15 August). Severe drought could wipe 0.6pc from 2018-19 GDP. Financial Review. Retrieved from https://www.afr.com/markets/citi-severe-drought-could-wipe06pc-from-201819-gdp-20180815-h13zm2

Ruggiero, V. and South, N. (2013). Toxic state-corporate crimes, neo-liberalism and green criminology: The hazards and legacies of the oil, chemical and mineral industries. 
International Journal for Crime, Justice and Social Democracy, 2(2), 12-26. https://doi.org/10.5204/ijcjsd.v2i2.115

Short, D. (2016). Redefining genocide: Settler colonialism, social death and ecocide. London, UK: Zed Books.

South, N. (2012). Climate change, environmental (in)security, conflict and crime. In S. Farrall, D. French and T. Ahmed (Eds.), Climate change: Legal and criminological implications (chapter 9). Oxford, UK: Hart.

South, N. and Brisman, A. (Eds.). (2013). The Routledge international handbook of green criminology. London, UK: Routledge. https://doi.org/10.4324/9780203093658

South, N. (2007). The "corporate colonisation of nature": Bio-prospecting, bio-piracy and the development of green criminology. In P. Beirne and N. South (Eds.), Issues in green criminology: Confronting harms against environments, humanity and other animals (pp. 230-247). London, UK: Routledge.

Steffen, W., Dean, A. and Rice, M. (2019). Weather Gone Wild: Climate change-fuelled extreme weather in 2018. Sydney, NSW: Climate Council of Australia Ltd.

Stretesky, P., Long, M. and Lynch, M. (2014). The treadmill of crime: Political economy and green criminology. London, UK: Routledge. https://doi.org/10.4324/9780203077092

Sullivan, K. (2019, 22 February). Mass fish kill due to "exceptional climate conditions", Government's interim report finds. ABC Rural News.

US Global Change Research Program. (2018). 2018 Impacts, risks, and adaptation in the United States: Fourth national climate assessment, Volume II (Report-in-Brief). Washington, DC: US Global Change Research Program.

Von Essen, E., Hansen, H., Kallstrom, H., Peterson, M. and Peterson, T. (2014).

Deconstructing the poaching phenomenon: A review of typologies for understanding illegal hunting. British Journal of Criminology, 54, 632-651.

https://doi.org/10.1093/bjc/azu022

Von Essen, E., Hansen, H., Kallstrom, H., Peterson, M. and Peterson, T. (2015). The radicalisation of rural resistance: How hunting counterpublics in the Nordic countries contribute to illegal hunting. Journal of Rural Studies, 39, 199-209. https://doi.org/10.1016/j.jrurstud.2014.11.001

Vorosmarty, C., McIntyre, P., Gessner, M., Dudgeon, D., Prusevich, A., Green, P., Gidden, S., Bunn, S., Sullivan, C., Liermann, C., Reidy, C., and Davies, P.M. (2010). Global threats to human water security and river biodiversity. Nature, 467, 555-561. https://doi.org/10.1038/nature09440

Werner, A. (2010). A review of seawater intrusion and its management in Australia. Hydrogeology Journal, 18, 281-285. https://doi.org/10.1007/s10040-009-0465-8

White, R. and Heckenberg, D. (2014). Green criminology: An introduction to the study of environmental harm. London, UK: Routledge.

https://doi.org/10.4324/9780203096109 


\section{Water theft in rural contexts - White}

White, R. (1998). Environmental criminology and Sydney water. Current Issues in Criminal Justice, 10(2), 214-219. https://doi.org/10.1080/10345329.1998.12036130

White, R. (2003). Environmental issues and the criminological imagination. Theoretical Criminology, 7(4): 483-506. https://doi.org/10.1177/13624806030074005

White, R. (2011). Transnational environmental crime: Toward an eco-global criminology. London, UK: Routledge.

White, R. (2013). Environmental harm: An eco-justice perspective. Bristol, UK: Policy Press. https://doi.org/10.1332/policypress/9781447300403.001.0001

White, R. (2017). Corruption and the securitisation of nature. International Journal of Crime, Justice and Social Democracy, 6(4): 55-70. https://doi.org/10.5204/ijcjsd.v6i4.449

White, R. (2018a). Climate change criminology. Bristol, UK: Policy Press. https://doi.org/10.1332/policypress/9781529203950.001.0001

White, R. (2018b). Ecocentrism and criminal justice. Theoretical Criminology, 22, 342-362. https://doi.org/10.1177/1362480618787178

Wilson, M. (1983). Folk crime: Patterns of accommodation. Deviant Behavior, 4(2): 123140. https://doi.org/10.1080/01639625.1983.9967607 